\title{
Mail Contact
}

National Cancer Institute

\section{Source}

National Cancer Institute. Mail Contact. NCI Thesaurus. Code C51834.

The person who is responsible for correspondence handled in a postal system, such as letters and packages. 